\title{
Research Article: Knowledge and adoption of SRI method paddy growers
}

\section{CHANNAMALLIKARJUNA AND SYED SADAQATH}

Article Chronicle : Received : 24.03.2017;

Revised : 03.04.2017; Accepted : 17.04.2017

KEY WoRDS :

Knowledge, Adoption, SRI method paddy

Author for correspondence : D. CHANNAMALLIKARJUNA Department of Agricultural Extension Education, University of Agricultural Sciences, DHARWAD (KARNATAKA) INDIA

Email:channa.agri@ gmail.com See end of the article for authors' affiliations
SUMMARY : The present study was undertaken in Dharwad and Kalaghatgi talukas of Dharwad district of Karnataka state having large area under cultivation of paddy, from selected talukas the list of villages was prepared and five villages from each taluka were selected on the basis of highest area under paddy crop. From selected villages, the list of farmers was prepared village wise and 15 farmers from each villages were selected by random sampling technique. Total 150 respondents were selected for the study. The data were collected by personal interview. Based on the finding of the study majority of the respondents were having medium level of knowledge, followed by high level and low level of knowledge. While in case of adoption, that majority of the respondents had medium level of adoption, followed by high and low level of adoption. Among various personal, socio-economic profile characteristics of the respondents, education, land holding, area under SRI method, family income, social participation, mass participation, had highly significant relationship with at 5 per cent level of adoption whereas experience in SRI method, innovative proneness, risk orientation, extension contact, participation in training, cosmopoliteness, farmers field school, had highly and positively significant relationship with at 1 per cent level of adoption whereas only age had non-significant relationship with the knowledge and adoption of SRI method paddy growers.

How to cite this article : Channamallikarjuna, D. and Sadaqath, Syed (2017). Knowledge and adoption of SRI method paddy growers. Agric. Update, 12(2): 277-280; DOI : 10.15740/HAS/AU/12.2/277-280. 